\title{
Development of Cell Guide Quality Management System for Container Ships
}

\author{
Bong-Rae Park ${ }^{*}$ and Hyun-Cheol Kim ${ }^{* *}$ \\ "WAPA SYSTEM, BUsan, Korea \\ ${ }^{* *}$ Faculty of Mechanical Engineering, Ulsan College, Ulsan, Korea \\ 컨테이너 선박의 셀 가이드 정도 관리 시스템 개발 \\ 박봉래 ${ }^{*}$ 김현철@* \\ "와파시스템 \\ *울산과학대학교 기계공학부
}

KEY WORDS: Cell guide 셀 가이드, Quality management 정도 관리, Quality inspection 정도 검사, Container Ship 컨테이너 선박

\begin{abstract}
Generally, container ships contain cargo holds with cell guides that serve to increase the container loading and unloading efficiency, minimize the space loss, and fix containers during the voyage. This paper describes a new quality management system for the cell guides of container ships (the so-called Trim Cell Guide system). The main functions of this system are the trimming of the point cloud obtained using a 3D scanner and an inspection simulation for cell guide quality. In other words, the raw point cloud of cell guides after construction is measured using a 3D scanner. Here, the raw point cloud contains a lot of noise and unnecessary information. Using the GUI interface supported by the system, the raw point cloud can be trimmed. The trimmed point cloud is used in a simulation for cell guide quality inspection. The RANSAC (Random Sample Consensus) algorithm is used for the transverse section representation of a cell guide at a certain height and applied for the calculation of the intervals between the cell guides and container. When the container hits the cell guides during the inspection simulation, the container is rotated horizontally and checked again for a possible collision. It focuses on a system that can be simulated with the same inspection process as in a shipyard. For a practicality review, we compared the precision data gained from an inspection simulation with the measured data. As a result, it was confirmed that these values were within approximately $\pm 2 \mathrm{~mm}$.
\end{abstract}

\section{1. 서 론}

일반적으로 컨테이너 선박에는 컨테이너를 적재하는 화물창 (Cargo hold)내에 격자형 구조물(Lattice type structure)인 셀 가이 드(Cell guide)가 설치되어 있다. 셀 가이드는 컨테이너의 하역 을 용이하게 하고 공간 손실을 최소화하여 적재 효율을 높이는 역할을 할 뿐 만 아니라, 항해 중 화물을 고정하는 역할을 한다. 셀 가이드는 화물창의 바닥면으로부터 하물창의 해치 코밍 (Hatch coaming)에 있는 나팔 모양의 엔트리 가이드(Entry guide) 까지 연결되어 있어서, 갠트리 크레인(Gantry crane)으로부터 내 려오는 컨테이너가 엔트리 가이드를 통해 바닥면까지 컨테이너 의 승 - 하강이 수직으로 원활하게 움직일 수 있도록 해야 한다. 그런데 실제 건조 현장에서 설치되는 셀 가이드는 다음과 같 은 이유들로 설계도면과 편차(Deviation)가 발생하여 컨테이너를
적재할 때 끼는 현상이나 넒은 유격으로 인해 흔들림 현상이 발생할 수 있다. 첫째, 선박 블록 탑재의 정밀도(Precision)가 떨 어지거나 연관된 블록의 용접 수축 및 팽창으로 인해 편차가 발생될 수 있다. 둘째, 선체 조립 과정에서 블록별 셀 가이드가 정확하게 정밀도 기준을 만족하더라도 선박 블록 탑재 조립 작 업을 거치면서 블록과 블록의 편차가 누적되어 결국 셀 가이드 와 셀 가이드 간의 편차를 가져올 수 있다. 따라서 컨테이너 선 박 건조 시 셀 가이드들이 규격화된 컨테이너를 허용 범위 내 에서 간섭 없이 적재될 수 있도록 정확히 시공되었는지를 측정 하는 셀 가이드 정도 검사는 컨테이너 적재 가능을 결정하는 중요한 작업 공정 중의 하나이다.

셀 가이드 정도를 검사하는 방법은 크게 실물 컨테이너(혹은 컨테이너 모형)(Container box)(SHI, 2000)을 사용하는 방법과 측 정 캐리지(Measurement carriage)(SHI, 2000; DSME, 2012; STX,

Received 22 December 2017, revised 8 May 2018, accepted 1 June 2018

Corresponding author Hyun-Cheol Kim: +82-052-279-3103, hckim@uc.ac.kr ORCID: http://orcid.org/0000-0001-9631-5645

(C) 2018, The Korean Society of Ocean Engineers

This is an open access article distributed under the terms of the creative commons attribution non-commercial license (http://creativecommons.org/licenses/by-nc/3.0) which permits unrestricted non-commercial use, distribution, and reproduction in any medium, provided the original work is properly cited. 


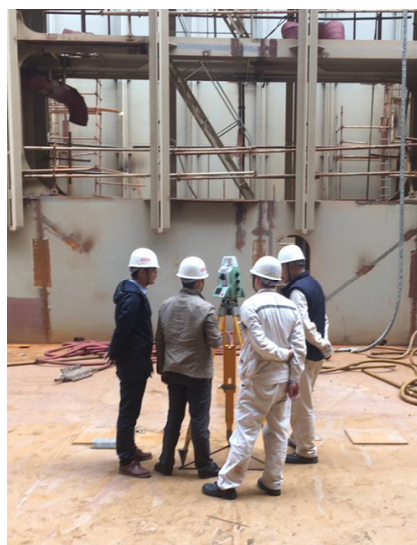

(a)

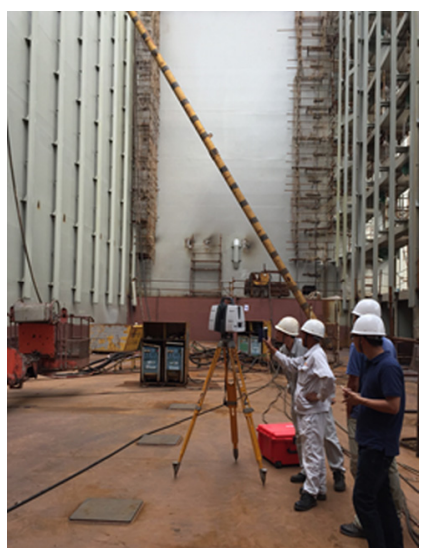

(b)
Fig. 1 Comparison of methods using a scan equipment - (a) Electro optical distance meter, (b) 3D scanner

2012), 측정센서 어셈블리(Measurement censor assembly)(DSME, 2014), 광파기(Electro optical distance meter) 등 측정 장비를 사 용하는 방법으로 구분할 수 있다. 실물 컨테이너를 사용하는 방 법은 크레인(Crane)을 이용하여 실물 컨테이너(혹은 컨테이너 모형)를 셀 가이드가 설치되어 있는 장소에 직접 넣어서 실제로 적재될 수 있는지 여부를 검사하는 것으로, 작업자가 화물창의 각 층 높이 위치에서 셀 가이드와 컨테이너 사이의 간격 (Interval)을 직접 측정한다. 이 방법은 시공된 셀 가이드의 정도 를 가장 확실하게 검사할 수 있지만, 크레인의 과다한 대기시간 으로 인한 타작업과의 마찰, 고소작업으로 인한 안전사고의 위 험성, 기상환경으로 인한 작업지연, 작업자들 간의 상호 수신호 에 의한 측정값 정밀도가 떨어지는 등의 단점들을 가지고 있다.

측정 캐리지나 측정센서 어셈블리를 사용하여 셀 가이드 사 이의 간격을 측정하는 방법은 측정 작업의 안정성과 정확한 계 측이 확보되는 장점이 있으나, 측정 장비의 설치 및 제거시 여 전히 사고의 위험성이 있으며, 장비 유지 보수에 고가의 비용이 소요되는 단점이 있다. 그리고 광파기를 사용하는 방법은 가장 안전하게 측정이 가능하지만, 획득된 데이터를 작업자가 원하 는 형태로 재가공하는 과정에서 많은 시간이 소요되고, 재가공 과정에서 입력 및 계산 오류의 발생 가능성을 포함하고 있어서 신뢰성 확보에 어려움이 있다(Fig. 1(a)).

최근에는 스캔장비(Scan equipment)(Fig. 1(b))를 이용하여 컨 테이너의 적재 여부를 컴퓨터 내에서 시뮬레이션(Simulation)하 여 검사하는 방법(HHI, 2014; HHI, 2015)이 소개되었다. 이것은 $3 \mathrm{D}$ 스캐너를 이용하여 지상에서 셀 가이드를 계측하여 $3 \mathrm{D}$ 데 이터를 확보한 후, $3 \mathrm{D}$ 데이터로 구성된 셀 가이드를 컴퓨터 내 에서 시뮬레이션을 통해 검사하는 방법으로, 안전사고의 위험 이 거의 없고, 짧은 스캔 소요 시간으로 인해 타 작업 공정과의 간섭이 적다. 또한, 최소 2 명의 인원으로도 검사가 가능하므로 작업 효율을 대폭 향상시킬 수 있는 장점을 가진다. 그러나 스 캔된 데이터의 후처리 과정이 복잡하여 일부 조선소에서는 $3 \mathrm{D}$ 스캐너 장비를 보유하고 있어도 실무에 적용하고 있지 않다. $\mathrm{HHI}(2014)$ 에서 소개된 방법도 구체적인 데이터 후 처리 방법 및 검사 시뮬레이션 시스템에 대해 언급하고 있지 않으며, 현재 실용화 연구도 없는 실정이다.
본 연구에서는 $3 \mathrm{D}$ 스캐너를 이용한 셀 가이드 정도 관리 시스 템(TrimCellGuide system: Cell guide quality management system for container ships)을 구체적인 개발 내용과 그 결과에 대해 다루었 다. 개발된 시스템의 구성, RANSAC(Random Sample Consensus) 알고리즘 적용 방법, 검사 시뮬레이션을 위한 컨테이너 조정 알 고리즘을 소개하고, 실제 계측된 데이터와의 비교 - 분석함으로 써 개발된 시스템의 성능과 신뢰성을 검증하였다.

\section{2. 셀 가이드 정도 관리 시스템}

\section{$2.13 \mathrm{D}$ 스캐닝 측정 방법}

컨테이너 선박의 셀 가이드를 $3 \mathrm{D}$ 스캐너로 계측할 때 화물창 (Cargo hold) 전체를 스캔하는 방법과 4개의 셀 가이드를 하나 의 그룹(이하 “셀 가이드 그룹”이라 함.)으로 하여 부분 스캔하 여 전체로 결합하는 방법이 있다. 화물창 전체를 스캔하는 방법 은 셀 가이드와 바닥부의 패드(Pad)와 소켓(Socket)을 포함하여 상세하게 스캔하기에는 한계가 있고 정밀도(Precision)도 떨어져 시률레이션을 위한 데이터로 사용하기가 어렵다. 또한, 스캔하 는 데에도 많은 시간이 소요된다. 실제 컨테이너 선박에는 각 화물창에 $15 \sim 18$ 개의 셀 가이드 그룹이 설치되어 있는데, 화물창 전체를 스캔할 경우 약 2 시간 정도, 셀 가이드 그룹은 약 8 분 정도 소요되었다. Fig. 2는 $3 \mathrm{D}$ 스캐너로 컨테이너 선박의 화물
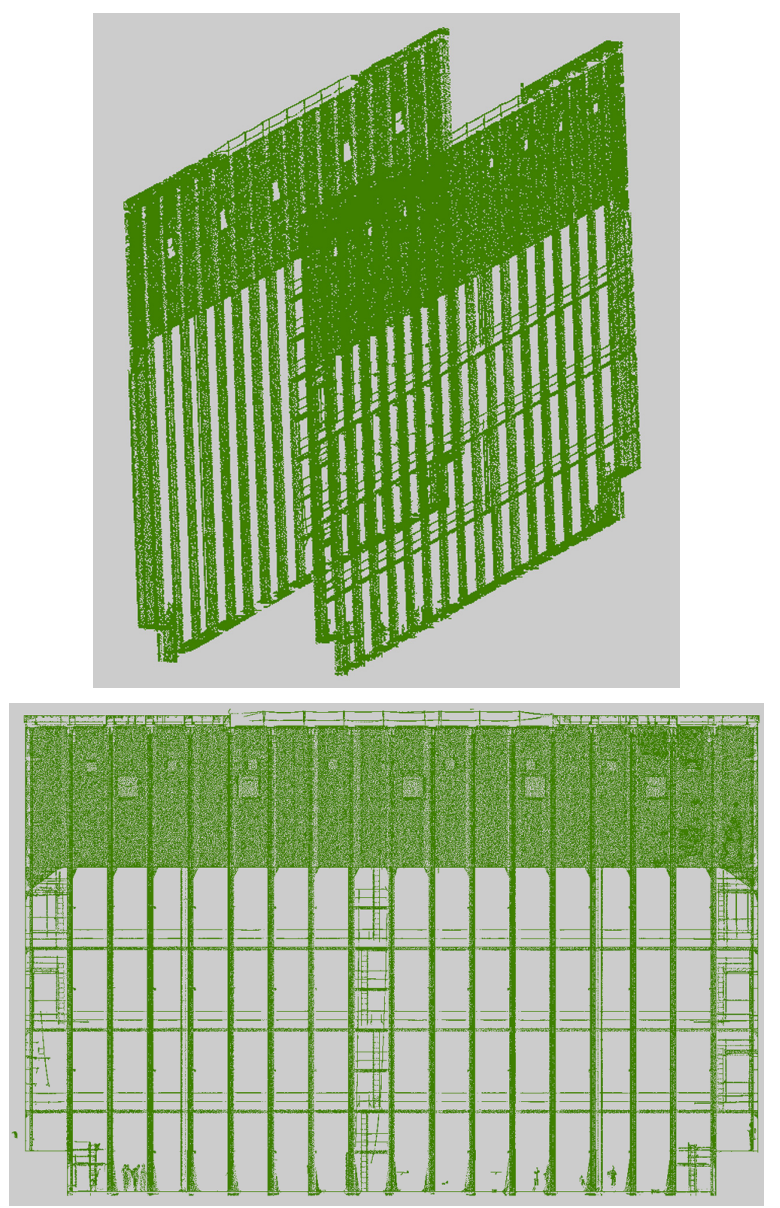

Fig. 2 3D scanned point cloud about cell guides within a cargo hold of container ship 
창 내 트랜스버스 박스(Transverse box) 벽면을 스캔한 점군 데 이터를 보여준다. 각 셀 가이드 그룹에 대해 형성된 점군 데이 터는 약 300 만개, 18 개의 전체에 대해서는 약 4,000 만 개 이상 의 점군 데이터를 형성하였다.

조선소에서는 일반적으로 컨테이너 모형을 이용하여 셀 가이 드들을 모두 검사하지 않고, 무작위로 샘플링(Sampling)하여 검 사를 수행한다. 따라서 본 연구에서도 검사 시간 단축과 정밀도 가 높은 측정을 위해 화물창 내에 임의의 셀 가이드 그룹을 샘 플링한 후 스캔하여 시뮬레이션을 위한 데이터로 활용하였다.

셀 가이드 계측을 위한 $3 \mathrm{D}$ 스캐너 설치 및 사용시 고려사항 은 다음과 같다(Fig. 1(b)).

(1) $3 \mathrm{D}$ 스캐너는 셀 가이드의 대각선 교점인 중앙에 위치시키 며, 스캐너 렌즈의 방향은 셀 가이드 정면을 바라보게 한다.

(2) 3D 스캐너 삼각대의 두 다리를 잡고 선정 위치 안착 후 중심을 잡으며 바닥에 완전히 고정시킨다. 이때 삼각대의 높이 를 조절할 때에는 최대 높이로 설정하지 않는 것이 좋다. 최대 높이로 설정하게 되면, 바람이나 진동에 흔들려 정확한 데이터 를 얻기 어렵기 때문이다.

(3) $3 \mathrm{D}$ 스캐너의 점군 데이터 레벨을 고급 단계로 설정하면 정 밀도가 높은 데이터를 확보할 수 있지만, 적재 시뮬레이션 위해 서는 불필요한 정보를 많이 포함하므로, 일반적으로 중간 단계 로 설정하여 스캔 작업을 수행하며 점군 데이터 양을 조절하여 필요한 정보를 필터링(Filtering)하여 사용한다. 중간 단계 설정의 경우에도 셀 가이드 그룹당 약 700 만개 이상의 점군 데이터가 형성되므로, 일반 컴퓨터에서 사용하기 어렵다. 따라서 셀 가이

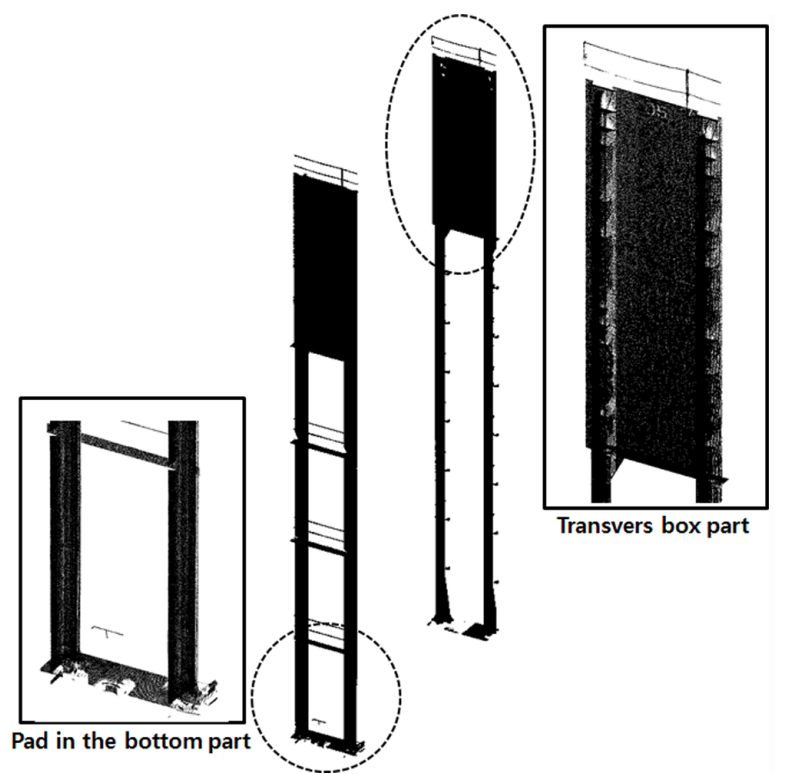

Fig. 3 An example of raw point cloud scanned about a cell guide group
드 부분만 따로 정리하여 약 300 만 개 450만 개 점군 데이터를 활용한다. 이때 셀 가이드와 함께 양 끝에 구조물인 바닥부의 소 켓(Socket)을 포함한 패드(Pad)와 해치커버(Hatch cover) 무게를 지탱하는 역할을 하는 트랜스버스 박스(Transverse box)가 모두 포함된다(Fig. 3). 여기서 셀 가이드만 따로 점군 데이터를 한 번 더 필터링(Filtering)하면 약 30 45만개 정도의 점군 데이터가 형 성된다. $3 \mathrm{D}$ 스캐너의 성능은 기후에 따라 영향을 받기 때문에, 안개가 심하거나 흐린 날은 피하는 것이 좋다.

\section{2 시스템 구성 및 기능 설계}

본 연구에서 개발한 컨테이너 선박의 셀 가이드 정도 관리 시 스템(Cell guide quality management system for container ships: TrimCellGuide system)은 3D 스캐너를 이용한 확보한 점군 데이 터를 이용하여 적재 시률레이션을 통해 셀 가이드의 적재 가능 여부를 검사하는 것을 목적으로 한다. 시스템의 내부 구성은 셀 가이드를 측정한 점군 데이터를 입력하여 검사 작업 준비를 하 는 프로젝트(Project) 기능, 점군 데이터의 정합(Coordination) 혹 은 노이즈 제거(Noise elimination) 등을 하는 필터링(Filtering) 기 능, 점군 데이터, 좌표 변환, 모델링 결과를 그래픽을 통해 보여 주는 뷰(View) 기능, 적재 시뮬레이션 기능 그리고 워크시트 (Work sheet) 출력 기능 등으로 구성된다(Fig. 4, Fig. 5).

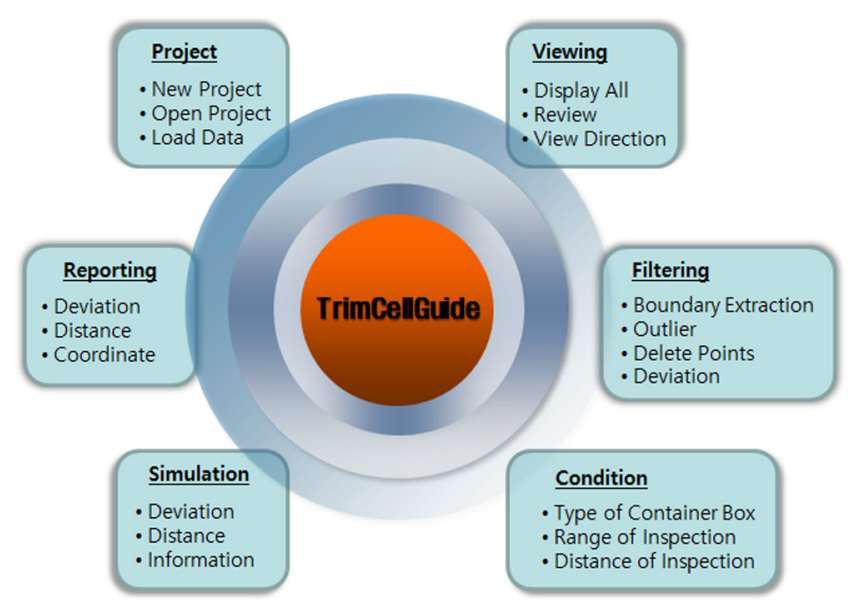

Fig. 4 Function diagram of TrimCellGuide System

\section{3 점군 데이터 처리}

2.3.1 스캔된 점군 데이터로부터 유효한 셀 가이드 정보 추출 실제 건조 현장에서 셀 가이드들은 여러 작업 환경 영향으로 인해 설계도면과 편차가 발생할 수 있다. Fig. 6에서 왼쪽의 검 정색 수직선은 Fig. 3과 같이 스캔된 셀 가이드 그룹에서 “그형 태의 셀 가이드 점군 데이터만을 필터링하여 나타낸 것이다. 그 리고 오른쪽 점들은 바닥 하부로부터 높이 방향으로 $5 \mathrm{~m}, 10 \mathrm{~m}$, $15 \mathrm{~m}, 20 \mathrm{~m}, 25 \mathrm{~m}$ 인 지점의 셀 가이드 단면을 나타내는 점군 데이

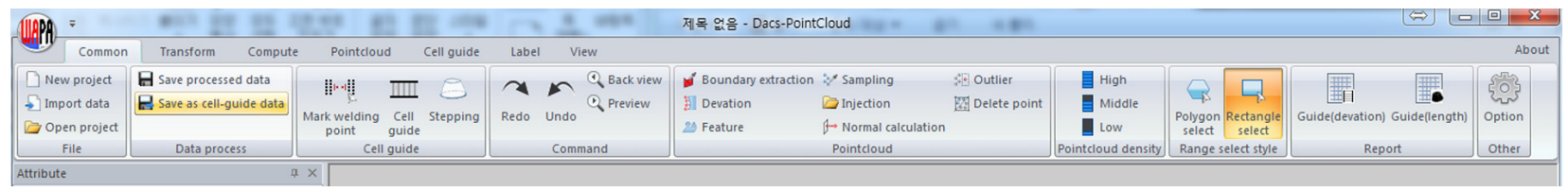

Fig. 5 Manu bar of TrimCellGuide System 


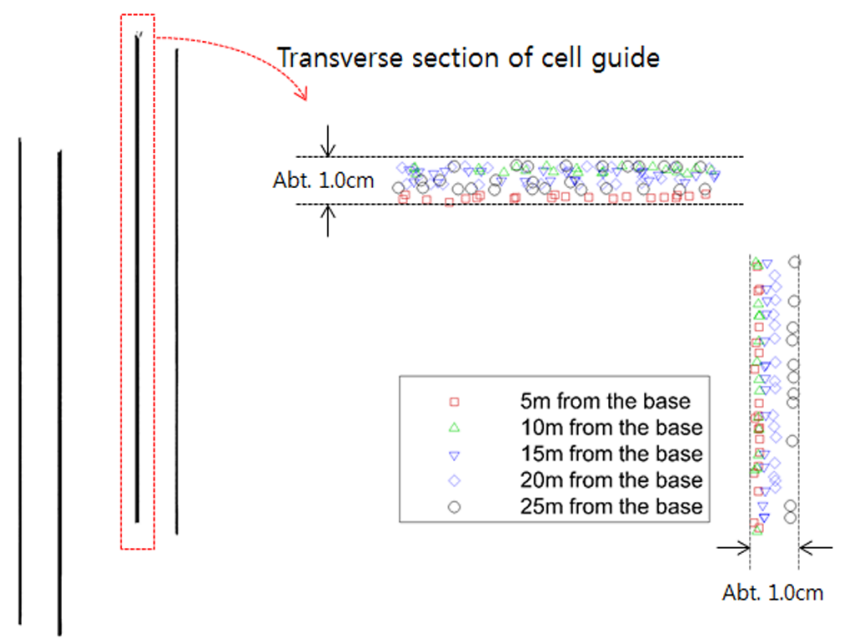

Fig. 6 Scanned point cloud at height $5 \mathrm{~m}, 10 \mathrm{~m}, 15 \mathrm{~m}, 20 \mathrm{~m}, 25 \mathrm{~m}$ from bottom

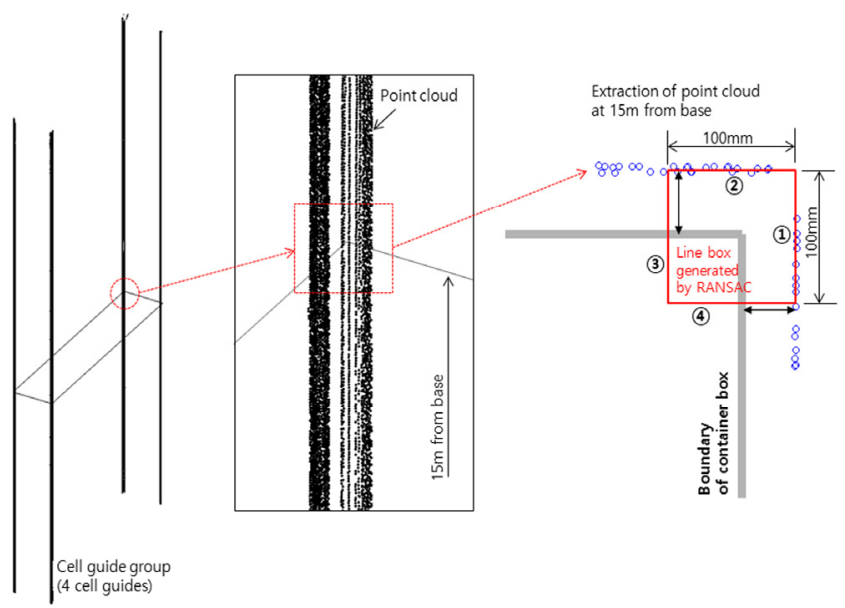

Fig. 7 Representation of a cell guide section at a certain height using RANSAC algorithm

터이다. 셀 가이드 단면들이 약 $1.0 \mathrm{~cm}$ 이내의 편차를 가지며 시 공되어 있음을 알 수 있다.

이러한 높이에 따른 셀 가이드 단면을 정확히 표현하기 위해 본 연구에서는 셀 가이드 전체를 $3 \mathrm{D}$ 모델링하지 않고 검사하고 자 하는 높이에 해당하는 셀 가이드 정보만 추출하는 방법을 사 용하였다(Fig. 7). 즉, 검사하고자 하는 높이에 해당하는 점군 데 이터만을 추출하여 대표 직선식으로 표현하였다. Fig. 7은 높이 $15 \mathrm{~m}$ 지점의 점군 데이터와 대표되는 직선 (1)과 (2)를 나타낸다. 이 때 선택된 점군 데이터는 노이즈와 유효하지 않은 데이터도 모두 포함하고 있으므로, 일반적인 보간 혹은 근사법 대신 밀집도 (Density)가 높은 유효한 데이터를 중심으로 대표 직선을 생성하 는 RANSAC 알고리즘(Ransom sample consensus algorithm)을 사 용하여 셀 가이드 단면 표현하였다(Fischler and Bolles, 1981). 여 기서 밀집도가 높다는 것은 생성된 근사선을 중심으로 스캔된 값 들이 집중되어 분포되어 있음을 의미한다. Fig. 7에서 RANSAC 알고리즘에 의해 생성된 사각형 영역(1), (2), (3), (4)은 $100 \mathrm{~mm}$ 이 내의 유격 허용 범위(Allowance area)를 나타낸다. 이들 유격 허용 범위는 조선소의 상황에 따라 다르게 정의될 수 있다.

\subsection{2 셀 가이드와 컨테이너 사이의 유격거리 계산}

Fig. 7에서 보는 바와 같이 RANSAC 알고리즘에 의해 생성된 곡선식으로부터 컨테이너와의 유격거리(Interval)를 계산할 수 있다. 즉, 임의 높이에서의 셀 가이드 직선식 $a x+b y+c=0$ 과 컨 테이너 상의 고정점 $\left(x_{1}, y_{1}\right)$ 사이의 간격은 식 (1)과 같이 간단 히 계산될 수 있다.

$$
d=\frac{\left|a x_{1}+b y_{1}+c\right|}{\sqrt{a^{2}+b^{2}}}
$$

그런데 컨테이너가 유격 허용 범위 내에 있는지를 검토해야 하므로 식 (1)은 식 (2)와 같은 조건이 시스템에 부가된다.

$\tilde{d}=d$, if the container is in the allowance area

$\tilde{d}=-d$, if the container is outside the allowance area

여기서 간격 $d$ 가 유격 허용 범위를 벗어나면 “-”값을 부여한다. 이는 시스템 내에서 컨테이너 적재시 셀 가이드와 컨테이너 사 이의 간격이 유격 허용 범위 밖에 있을 경우 수정 작업을 해야 함으로 나타낸다.

식 (1)과 식 (2)로부터 컨테이너 네 모서리 근처에서의 셀 가이 드 유격거리의 전체 합 $\delta$ 는 다음 식 (3)과 같이 계산될 수 있다.

$$
\delta=\sum_{i=1}^{4} \sum_{j=1}^{n} \widetilde{d_{i j}}=\sum_{i=1}^{4} \sum_{j=1}^{2} \frac{\left|a_{i} x_{i j}+b_{i} y_{i j}+c_{i}\right|}{\sqrt{a_{i}^{2}+b_{i}^{2}}}
$$

여기서 $a_{i}, b_{i}, c_{i}$ 는 $\mathrm{A}, \mathrm{B}, \mathrm{C}, \mathrm{D}$ 네 지점에 위치하는 셀 가이드를 나타내는 직선식의 계수들이다. 그리고 $\left(x_{i j}, y_{i j}\right)$ 는 측정하고자 하는 위치의 컨테이너 좌표 $\mathrm{X}_{1}, \mathrm{X}_{2}, \mathrm{Y}_{1}, \mathrm{Y}_{2}$ 를 나타낸다(Fig. 8).

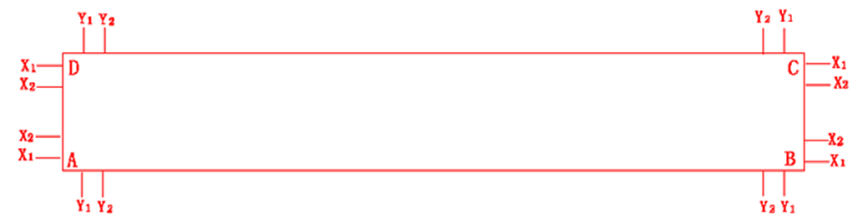

(a)

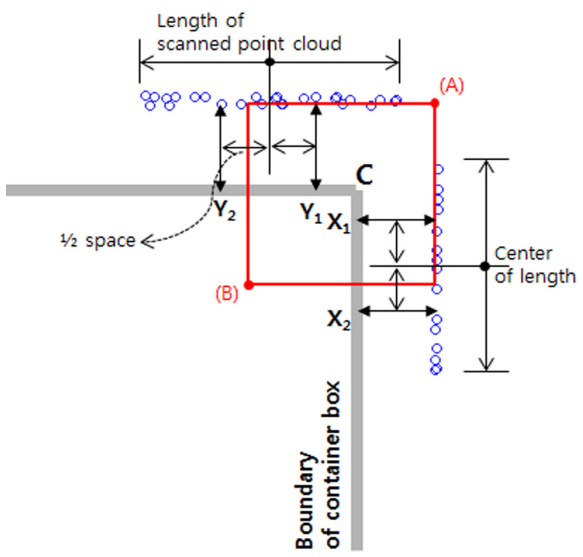

(b)

Fig. 8 Two positions at each corner for the interval calculation between cell guides and a container 


\subsection{3 컨테이너 적재 조정 방법}

컨테이너 적재 시뮬레이션에서 컨테이너 중심점은 셀 가이드 들의 교차점과 컨테이너 네 모서리의 교차점을 일치시켜 승/하 강을 하여 적재 가능 여부를 검사한다. 이때 충돌이 발생할 경 우 조선소에서는 컨테이너를 일정 각도로 회전하여 적재 여부 를 재검사한다. 그리고 컨테이너가 내려갈 공간이 확인되면 셀 가이드 적재가 이상이 없는 것으로 판단한다. 따라서 본 연구에 서 개발된 시스템에서도 적재 시뮬레이션에 이러한 조정 기능 을 부여하여 자동적으로 컨테이너가 회전하여 적재 가능 여부 를 검사하도록 하였다(Fig. 9).

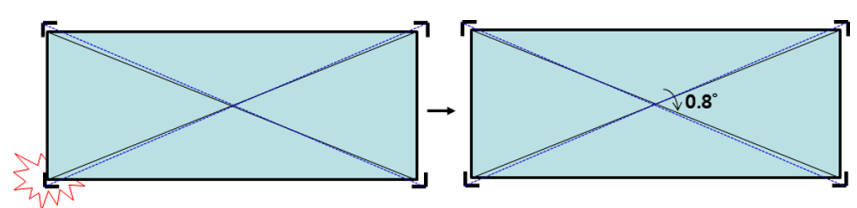

Fig. 9 Correction of container loading method using an automatic rotation

컨테이너 적재 조정 방법은 다음과 같다.

Step 1: 임의 높이에 해당하는 셀 가이드 단면에 대해 컨테이 너 네 모서리에서 식 (3)의 유격 거리 $\widetilde{d_{i j}}$ 를 계산한다.

Step 2: 컨테이너 각 모서리에서 $\widetilde{d_{i j}}$ 에 대해 충돌 여부를 평가 한다.

Step 3: 충돌이 확인되면 식 (4)와 같이 유격 거리의 전체 합 $\left(\delta_{\theta}\right)$ 이 최대가 되도록 회전각을 결정한다.

$\operatorname{maximize} \delta_{\theta}$ at $\theta$
여기서 $\delta_{\theta}$ 는 임의 회전각 $\theta$ 에서의 유격거리의 전체 합을 나타 낸다.

Step 4: 컨테이너 각 모서리에서 $\widetilde{d_{i j}}$ 에 대해 충돌 여부를 재평 가한다.

Step 5: 검사 결과를 워크시트(Work sheet)로 출력한다.

\section{4 컨테이너 적재 시뮬레이션}

TrimCellGuide 시스템은 3D 스캐너로 확보된 점군 데이터를 기 반으로 적재 시뮬레이션을 통해 셀 가이드의 시공 상태를 검사하 는 것을 목적으로 개발되었다. Fig. 10은 컨테이너 적재 시뮬레이 터를 이용한 셀 가이드 정도 검사 작업 과정 흐름도를 나타낸다. 컨테이너선 화물창 내에 셀 가이드들이 시공되면, $3 \mathrm{D}$ 스캐너를 통해 스캔하여 셀 가이드에 대한 점군 데이터를 확보한다. 확보 된 점군 데이터를 바탕으로 TrimCellGuide시스템의 검사 시뮬레 이션을 통해 적재 가능 여부를 검토한 후, 그 결과를 워크시트로 출력한다. 이때 워크시트에는 충돌이 생긴 셀 가이드 부분에 대 해 수정 작업을 할 수 있도록 정확한 위치와 유격정보(Interval between cell guides and container box)를 나타낸다.

적재 시뮬레이션은 Fig. 11에서와 같이 왼쪽의 조건 설정 화 면과 오른쪽 결과를 보여주는 메인 화면으로 구성된다. 조건 설 정 화면에서는 시뮬레이션을 위해 필요한 조건들을 정의하며, 각 항목의 내용들을 살펴보면 다음과 같다.

- Container type : 컨테이너 규격 설정(여기서는 40fit로 정의 되어 있음.)

- Container length, width, height : 컨테이너 크기 정의

- Longitudinal tolerance : 컨테이너 길이방향의 허용 오차 범위

- Horizontal tolerance : 컨테이너 횡방향의 허용 오차 범위

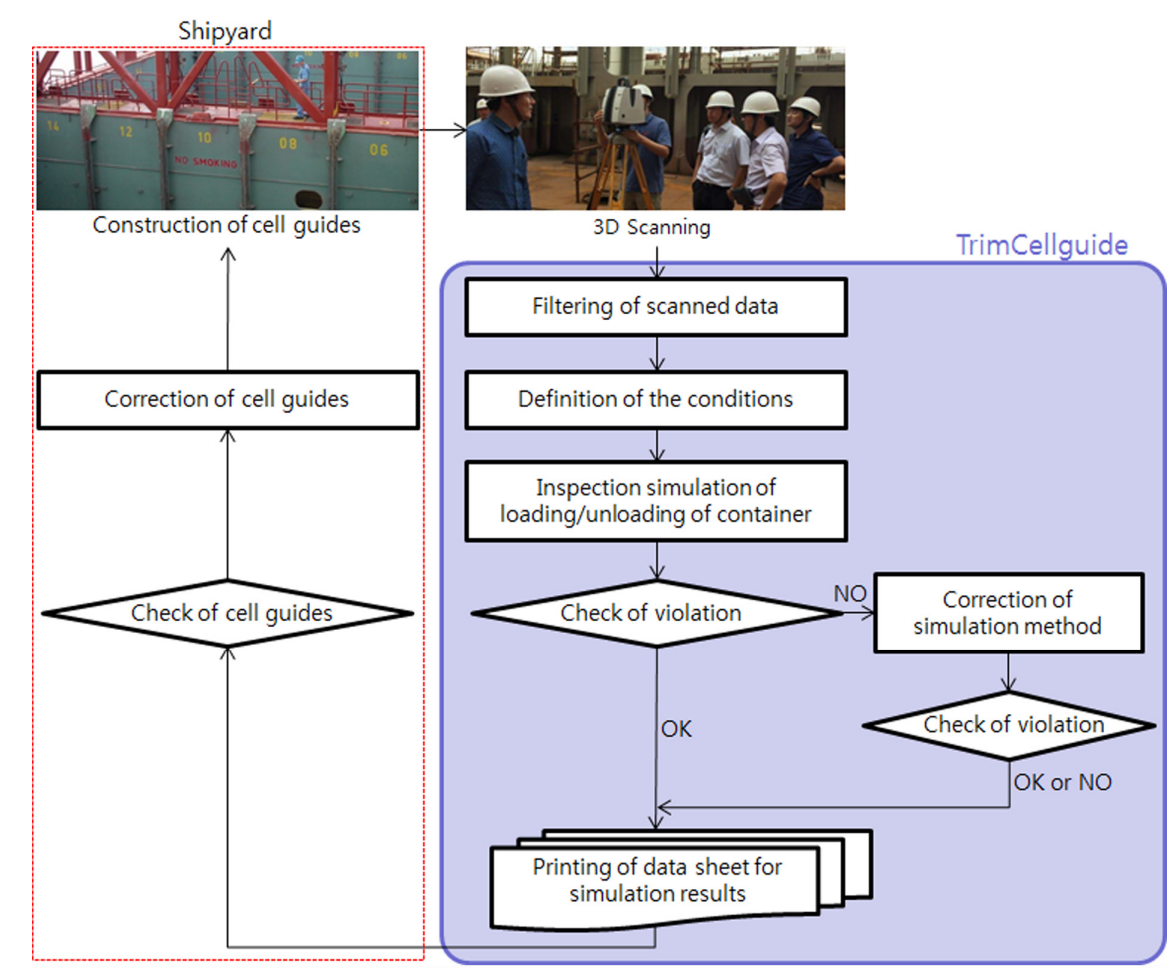

Fig. 10 Workflow of cell guides inspection test using 3D scanner and simulation 


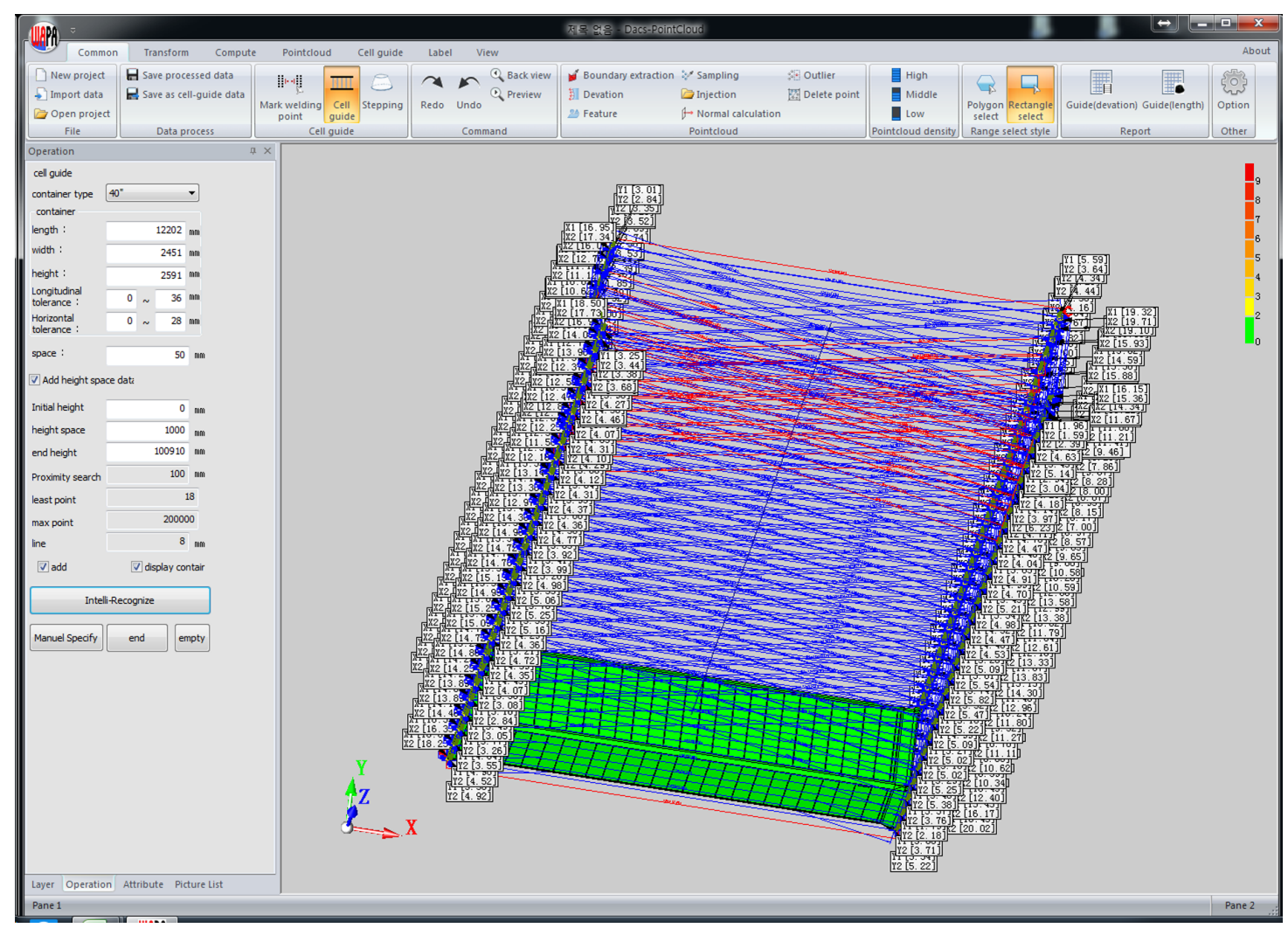

Fig. 11 Condition definition and result for the simulation of container cell guide inspection

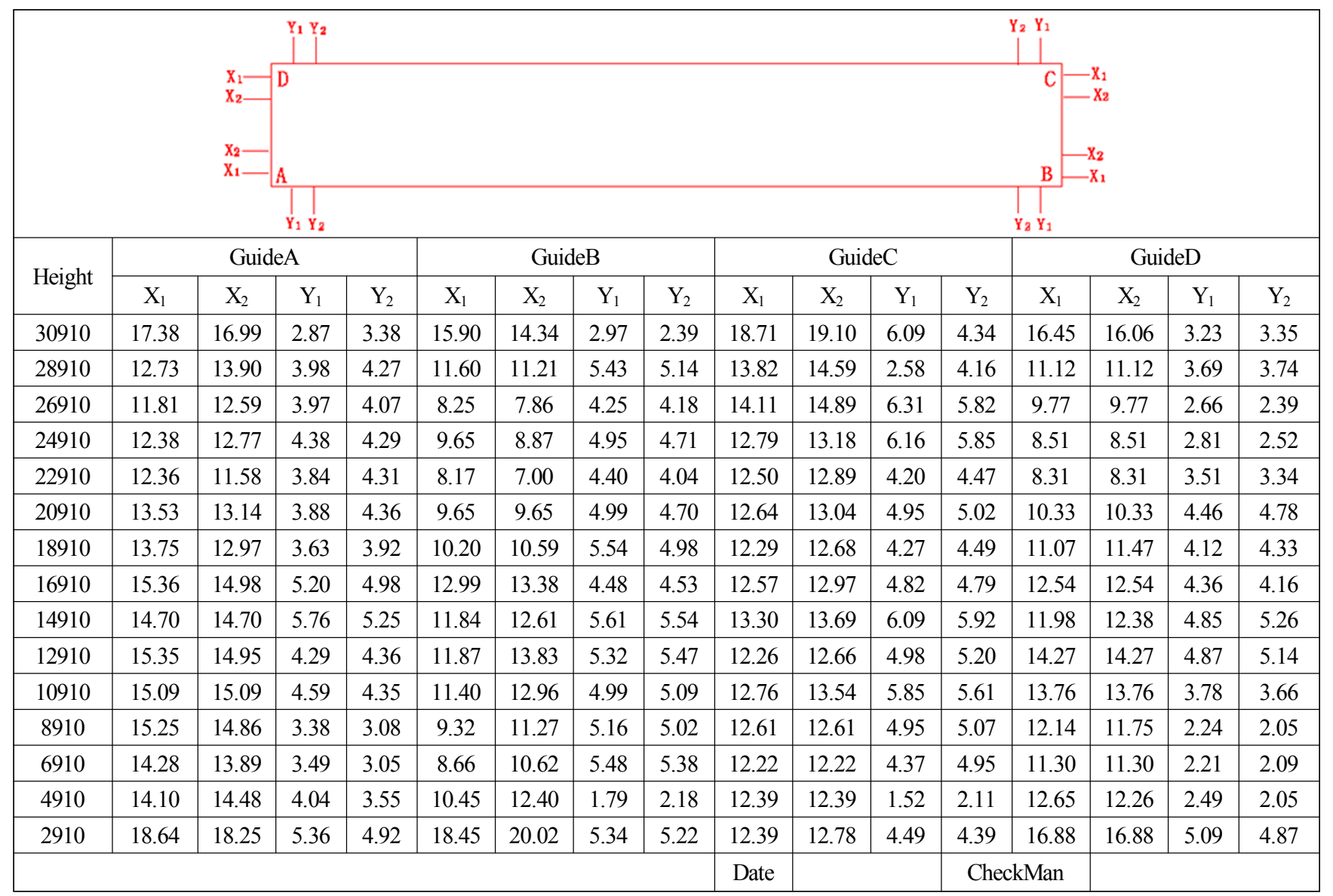

Fig. 12 Final report after the simulation of container cell guide inspection 
- Space : 셀 가이드와 컨테이너사이의 간격을 계산할 위치

- Initial \& End height : 검사할 시작과 끝 높이

- Height space : 검사 간격

- Inteli-Recognize : 시뮬레이션 실행

- 그 외 항목: Default로 주어지므로 사용자가 설정할 사항이 아님.

상기 조건들을 정의한 후, 시뮬레이션을 실행하면 그 결과로 서 각 높이마다 셀 가이드와 컨테이너 사이에 간격과 기타 정 보를 메인 화면에 나타난다. 검사하고자 하는 높이가 많이 있을 경우 메인 화면에 도시된 결과를 사용자가 파악하기가 쉽지 않 다. 따라서 시뮬레이션 결과를 쉽게 파악할 수 있도록 그 결과 를 Fig. 12와 같이 워크시트로 출력하였다. Guide A, B, C, D는 각 컨테이너 모서리에서의 셀 가이드를 나타내고, $\mathrm{X}_{1}, \mathrm{X}_{2}$ 와 $\mathrm{Y}_{1}$, $\mathrm{Y}_{2}$ 는 각각 길이 방향과 폭 방향으로 두 군데에서 유격 거리를 계산한 값들을 나타낸다. $\mathrm{X}_{1}, \mathrm{X}_{2}$ 와 $\mathrm{Y}_{1}, \mathrm{Y}_{2}$ 값을 비교한 결과 각 각 평균 $-0.08 \mathrm{~mm} \sim 0.45 \mathrm{~mm}$ 범위에서 셀 가이드 유격 거리 계 산 편차가 있음을 확인하였다.

\section{3. 비교 및 분석}

개발된 "TrimCellGuide시스템"의 성능 검증을 위해 실제 셀 가 이드와 컨테이너 사이의 유격거리 측정값과 시뮬레이션을 수행하 여 계산한 결과를 비교하였다. 조선소에서 실제 컨테이너를 이용 하여 적재 검사를 할 경우 안전사고의 위험이 있으므로 충돌이 감지될 때에만 수정 작업을 위해 셀 가이드와 컨테이너 사이의 유격거리를 측정한다. 그러나 본 연구에서는 시뮬레이션 결과와 의 실제 계측 값을 비교하기 위해 세 지점의 높이방향에서 유격거 리를 측정하였다. 대상 선박은 $\mathrm{S}$ 조선소의 $2,500 \mathrm{TEU}$ 컨테이너 선 박이며, 셀 가이드 계측 위치는 높이 방향으로는 $3.0 \mathrm{~m}$ 간격으로 $3.2 \mathrm{~m}, 6.2 \mathrm{~m}, 9.2 \mathrm{~m}$ 그리고 각 끝 단면으로부터 약 $50 \mathrm{~mm}$ 지점(모서 리에서 $115 \mathrm{~mm}$ 지점)에서 유격 거리를 측정하였다(Fig. 13).

실제 계측할 때 컨테이너가 승/하강하는 중 안전사고 위험으 로 인해 정해진 높이에서 정확히 동일한 위치에서의 셀 가이드 와 컨테이너 간격을 계측하는 것이 현실적으로 어렵지만, 가능 한 근접한 장소에서 계측하였다.

Table 1과 Fig. 14는 측정값과 시률레이션 결과를 비교한 것으 로, 그 차이가 약 $\pm 2 \mathrm{~mm}$ 범위에 있음 알 알 수 있다. 이는 $3 \mathrm{D}$ 스캐 너를 이용하여 안전하게 검사하고자 하는 화물창 내에서 셀 가이 드를 측정한 후, 시뮬레이션 과정을 거쳐 필요한 셀 가이드 시공 정보를 검사하는 데에 실제 적용 가능한 수준임을 보여준다.
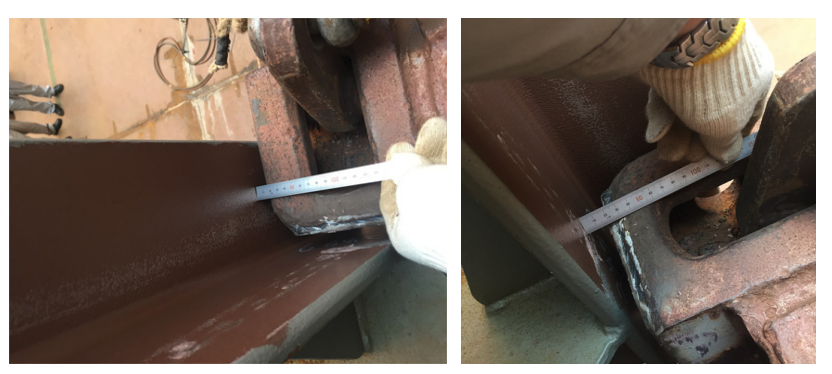

Fig. 13 Interval measurement between cell guide and container box
Table 1 Comparison between measured data and simulation results [unit: $\mathrm{mm}$ ]

\begin{tabular}{|c|c|c|c|c|c|}
\hline Height & Cell & guide & $\begin{array}{c}\text { Measured } \\
\text { value }\end{array}$ & $\begin{array}{c}\text { Calculated } \\
\text { value }\end{array}$ & Difference \\
\hline \multirow{8}{*}{9,200} & \multirow{2}{*}{ A } & $\mathrm{X}$ & 20 & 19.97 & -0.03 \\
\hline & & $\mathrm{Y}$ & 9 & 9.92 & 0.92 \\
\hline & \multirow{2}{*}{ B } & $\mathrm{X}$ & 17 & 17.08 & 0.08 \\
\hline & & $\mathrm{Y}$ & 11 & 11.72 & 0.72 \\
\hline & \multirow{2}{*}{$\mathrm{C}$} & $X$ & 16 & 17.86 & 1.86 \\
\hline & & $\mathrm{Y}$ & 13 & 11.79 & -1.21 \\
\hline & \multirow{2}{*}{$\mathrm{D}$} & $X$ & 15 & 16.88 & 1.88 \\
\hline & & $\mathrm{Y}$ & 10 & 8.74 & -1.26 \\
\hline \multirow{8}{*}{6,200} & \multirow{2}{*}{ A } & $\mathrm{X}$ & 19 & 18.93 & -0.07 \\
\hline & & $\mathrm{Y}$ & 8 & 9.78 & 1.78 \\
\hline & \multirow{2}{*}{ B } & $X$ & 15 & 16.03 & 1.03 \\
\hline & & $\mathrm{Y}$ & 10 & 10.64 & 0.64 \\
\hline & \multirow{2}{*}{$\mathrm{C}$} & $\mathrm{X}$ & 18 & 17.77 & -0.23 \\
\hline & & $\mathrm{Y}$ & 11 & 10.78 & -0.22 \\
\hline & \multirow{2}{*}{$\mathrm{D}$} & $X$ & 16 & 16.24 & 0.24 \\
\hline & & $\mathrm{Y}$ & 10 & 8.01 & -1.99 \\
\hline \multirow{8}{*}{3,200} & \multirow{2}{*}{ A } & $\mathrm{X}$ & 24 & 22.9 & -1.10 \\
\hline & & $\mathrm{Y}$ & 10 & 11.16 & 1.16 \\
\hline & \multirow{2}{*}{ B } & $X$ & 23 & 24.15 & 1.15 \\
\hline & & $\mathrm{Y}$ & 12 & 11.06 & -0.94 \\
\hline & \multirow{2}{*}{$\mathrm{C}$} & $X$ & 18 & 17.14 & -0.86 \\
\hline & & $\mathrm{Y}$ & 10 & 10.28 & 0.28 \\
\hline & \multirow{2}{*}{$\mathrm{D}$} & $X$ & 22 & 21.4 & -0.60 \\
\hline & & $\mathrm{Y}$ & 11 & 10.72 & -0.28 \\
\hline
\end{tabular}

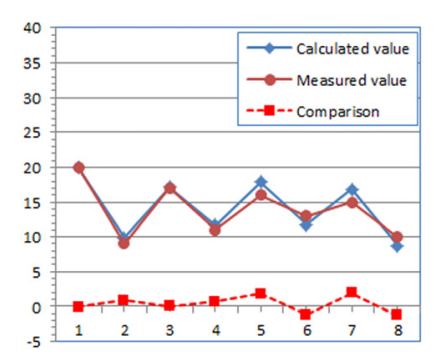

(a) Comparison of interval at height $3,200 \mathrm{~mm}$

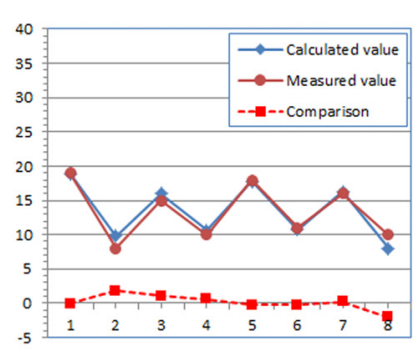

(b) Comparison of interval at height $6,200 \mathrm{~mm}$

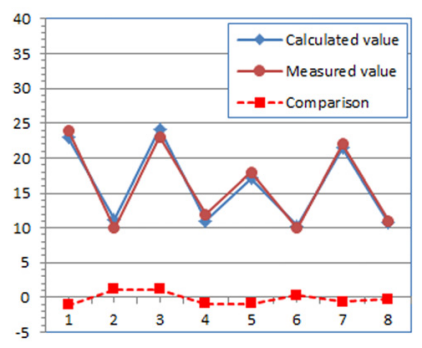

(c) Comparison of interval at height $9,200 \mathrm{~mm}$

Fig. 14 Comparison between measured data and simulation results 


\section{4. 결 론}

셀 가이드의 측정 및 적재 가능 여부에 대한 검사는 컨테이너 선박 건조에서 컨테이너 운송 및 적재 기능과 연관된 중요한 작 업으로, 안전사고의 위험성을 가지며 많은 시간을 필요로 한다. 주로 조선소를 중심으로 연구가 수행되었기 때문에 학술 논문보 다는 특허를 통해 실용적인 적용 방법이 소개되었다. 본 연구는 최근 급속하게 발달하고 있는 $3 \mathrm{D}$ 스캐너 기술을 이용하여 컨테 이너 셀 가이드를 계측한 후, 점군 데이터 처리를 통해 적재 시 뮬레이션를 수행하는 시스템을 개발하여, 실용적인 관점에서 그 결과를 검토하였다. 개발 내용을 요약하면 다음과 같다.

첫째, $3 \mathrm{D}$ 스캔한 셀 가이드의 점군 데이터로부터 컨테이너 적재 검사를 수행할 수 있는 자체 시스템을 구축하였다. 개발된 시스템은 컨테이너 적재 여부 검사, 컨테이너와 셀 가이드사이 의 유격거리 출력, 보고서 작성 등을 효율적이고 간편하게 수행 하게 한다.

둘째, 본 연구의 목적은 셀 가이드의 3D 모델링이 아니라, 시 공 결과 검사를 목적으로 하므로 검사하고자 하는 높이에서의 정확한 단면 표현을 위해 RANSAC를 적용하여 셀 가이드들과 컨테이너와의 유격거리를 계산하였다.

셋째, 컨테이너 적재 시률레이션에서 컨테이너가 셀 가이드와 충돌 시 컨테이너를 회전하여 조정할 수 있도록 시스템을 구현 하였다.

넷째, 개발된 시스템의 적재 시뮬레이션 결과를 실제 셀 가이 드 계측값과 비교한 결과 약 $\pm 2 \mathrm{~mm}$ 이내에서 일치함을 확인하였 으며, 실용적인 측면에서 신뢰성 있는 결과임을 보여주었다.

본 연구에서의 개발한 방법은 화물창 바닥에 $3 \mathrm{D}$ 스캐너를 설 치하여 소수의 인원으로만 셀 가이드를 측정하므로 기존 방법 들에 비해 안전사고의 위험이 거의 없다. 그리고 스캔된 점군 데이터로부터 1 시간 이내에 시뮬레이션이 가능하므로 현장에서 효율적으로 적용 가능할 것으로 기대된다. 현재는 적재 시뮬레 이션 과정에서 컨테이너가 셀 가이드에서 충돌 시 평면적으로 회전을 하여 적재 여부 가능성을 검사하지만, 향후에는 공간 회 전도 수행함으로써 보다 조정 기능을 강화할 계획이다.

\section{후기}

본 연구는 2017년 울산과학대학교 교내학술연구비 지원에 의 해 수행되었습니다.

\section{References}

Fischler, M.A., Bolles, R.C., 1981. Random Sample Consensus: A Paradigm for Model Fitting with Applications to Image Analysis and Automated Cartography. Communication of the ACM, 24(6), 381-395.

Daewoo Shipbuilding \& Marine Emgineering(DSME), 2012. Inspection Apparatus and Inspection Method of Container Cell Guide. Patent Application 10-2012-0008946, Korean Intellectual Property Office.

Daewoo Shipbuilding \& Marine Emgineering(DSME), 2014. System for the Measuring of Container Cell Guide Distance. Patent Application 10-2014-0068255, Korean Intellectual Property Office.

Hyundae Heavy Industries(HHI), 2014. Container Loading Mistake Test Device of Containership and Test Method. Patent Application 10-2014-0074537, Korean Intellectual Property Office.

Hyundae Heavy Industries(HHI), 2015. Vertual Inspection Method for Loading Container and Virtual Inspection System for Loading Container. Patent Application 10-2015-0181818, Korean Intellectual Property Office.

Samsung Heavy Industries(SHI), 2000. Measuring System and Inspection Method of Container Guide. Patent Application 102000-0063742, Korean Intellectual Property Office.

STX Daewoo Offshore \& Shipbuilding(STX), 2012. Cell Guide measuring System for Ship. Patent Application 10-20120079095, Korean Intellectual Property Office. 